\title{
Effects of Excess Cash Holdings on Firm Value: Study from the Perspective of Corporate Life Cycle
}

\author{
Zhijian Zeng, Xing Zhou \\ College of Business Administration, Hunan University, Changsha City, Hunan Province, 410082, China \\ zengzhijian@hnu.edu.cn, zhouxingcindy@163.com
}

\begin{abstract}
Based on the corporate life cycle theory, the effects of corporate excess cash holdings on firm value is conducted in this paper. The results show that a significant inverse U-shaped relation exists between excess cash holdings level and firm value. It indicates that lots of companies face the problem of financing constraints. Moreover, the results also show that the optimal excess cash holdings level is discrepant at different corporate life cycle stages. Therefore, in order to ensure the corporate cash policy is reasonable, the corporate should make the cash policy according to which corporate life cycle stage it is at.
\end{abstract}

Index Terms - Excess cash holdings level, Firm value, Corporate life cycle

\section{Introduction}

Cash is an important part of firm's assets. The firms in both developed markets and developing markets incline to hold large amount of cash in recent 20 years. The latest data of (Standard \& Poor) Capital IQ reveal that the cash assets of the companies in the Europe Debt 1000 up to 1100 billion euros in recently, which is on 21 percentage point higher than that in 2008 [1]. In the context of this reality, the motivation of cash holdings has been widely studied.

Some scholars think that the cash holdings motive of a firm is precaution[2]. Firms need to hold some cash to better cope with adverse shocks when access to capital markets is costly. From this view point, excess cash holdings benefit the firm value. Other scholars argue that managers would prefer to hold large amount of cash to provide a convenient for them to deriving private benefits[3]. From this view point, the amount of excess cash holdings has a negative relationship with firm value.

From above study, we can find that it is necessary to examine the effects of the excess cash holding on firm value by synthetically considering the above two viewpoints. We consider that the corporate life cycle may exert significant influence on the efficiency of corporate decisions. We investigate the effects of excess cash holdings on firm value based on the corporate life cycle theory. We hope that our study can enrich the research about excess cash holdings and firm value.

\section{Theoretical analysis}

The financial hierarchy theory suggests that raising external financing is more costly than raising internal financing in imperfect market[4]. Firms always have to give up some good investments if they short of cash and can't raise enough cash from external market at a proper cost. Holding some excess cash for a rainy day can prevent the firm from raising external financing at high cost, when the firm faces serious financing constraints. Chinese financial market is imperfect and lacks of effective operating mechanism, so Chinese firms always face serious financing constraints. Chinese firms need to hold some excess cash to meet their unanticipated contingencies, because the cost of other financing resources may be high. In this context, the managers' choice of holding some excess cash is reasonable. Excess cash holdings can help firms to seize the good investments. Thus, the excess cash holdings could exert positive impacts on firm value.

But the agency theories predict that due to the existence of agency conflict, managers and controlling shareholders may exploit some resources to derive private benefits[5]. Among the firm's assets, excess cash are particularly vulnerable. On the one hand, cash is easier to divert than fixed assets. On the other hand, keeping track of where cash actually goes is difficult. Chinese firms always face the following two kinds of agency problems at the same time. One is that the agency conflict between managers and shareholders. The other one is that the agency conflict between large shareholders and minority shareholders. In addition, the corporate governance of Chinese companies is weak, so it can't alleviate agency problems the firm faced effectively. Therefore, the negative effects of excess cash holdings on firm value should not be ignored.

Based on the above analysis, we can know that excess cash holdings have both positive impacts and negative impacts on firm value. The positive impacts outweigh the negative impacts when the excess cash holding level is low. The negative impacts outweigh the positive impacts when the excess cash holdings level exceeds a certain point. Therefore, we hypothesize that there is inverse U-shaped relation exists between excess cash holdings level and firm value.

We also hypothesize that the optimal excess cash holdings level which makes the firm value reaches maximum should be discrepant at different life cycle stages, because every aspect of firms has some special characteristics at each life cycle stages. On the one hand, the severity of financing constraints and agency conflicts the firms faced are discrepant at different life cycle stages, so the impacts of excess cash holdings on firm value certainly are different. On the other hand, the different excess cash holdings' motivations may lead to that the optimal excess cash holdings level is discrepant at different life cycle stages. 


\section{Data and variables}

\section{A. Sample selection}

The data of Chinese listed companies during the period from 2007 to 2012 are selected as research samples. The data obtains from the China stock market and accounting research database (http://www.gtarsc.com). The following firms in samples are removed: (1) financial, insurance firms and the like; (2) ST (Special Treated) firms; (3) the firms whose key indicators used in the excess cash holdings variables, Firm value variables and corporate life cycle variables are incomplete.

\section{B. The excess cash holdings variable}

We use the cash holdings estimation model presented by Dittmar and Mahrt-Smith to estimate the normal cash holdings level of one firm ${ }^{[6]}$. We add the two variables: financial leverage and dividend dummy variable in estimation model. The final model is as follow:

$$
\begin{aligned}
\operatorname{Ln}_{\left(\text {Cash }_{i, t}\right)} & =a_{0}+a_{1} \operatorname{Ln}\left(N A_{i, t}\right)+a_{2} \frac{N W C_{i, t}}{N A_{i, t}}+a_{3} \frac{C F O_{i, t}}{N A_{i, t}} \\
& +a_{4} \frac{R \& D_{i, t}}{N A_{i, t}}+a_{5} \frac{M V_{i, t}}{N A_{i, t}}+a_{6} \text { Leverage }_{i, t} \\
& +a_{7}\left({\text { IndustrySigma })_{i, t}}_{i}+a_{8} \text { Div_dummy }_{i, t}+e_{i, t}\right.
\end{aligned}
$$

Corporate cash holdings level (Cash) is the ratio of cash and cash equivalents to net assets. $N A$ is the net assets, defined as the difference between total assets and cash. $N W C$ denotes the net working capital, which is the difference between liquid assets and cash. $C F O$ denotes the net cash flows of operating activities. $R \& D$ is the research and development expense. When $R \& D$ is missing, we set its value to zero. $M V$ denotes the market value of a company. Leverage denotes the financial leverage, which is defined as the ratio of the total liabilities to total assets. Industry cash flow volatility (IndustrySigma) is represented by industry-average standard deviation of CFO/NA during the period of 2002 to 2006. A dividend dummy variable Div_dummy is defined to mark firms which pay dividends in a fiscal year. The $\varepsilon, i$ and $t$ denotes residual, the specific listed firms and the specific year respectively.

The dependent variable, $\operatorname{Ln}($ Cash $)$, in equation (1) is the natural logarithm of actual cash holdings level. The residual $\varepsilon$ of the equation (1) is the difference between the natural logarithm of actual cash holdings level and the natural logarithm of normal cash holdings level. Thus the normal cash holdings level (Normalcash) can be expressed as follow:

$$
\text { Normalcash }_{i, t}=\exp \left[\operatorname{Ln}\left(\operatorname{cash}_{i, t}\right)-e_{i, t}\right]
$$

The excess cash holdings level (Extracash) is the difference between actual cash holdings level (Cash) and predicted normal cash holdings level (Normalcash). So the equation (3) for calculating excess cash holdings level is as follow:

$$
\text { Extracash }_{i, t}=\text { Cash }_{i, t}-\text { NormalCash }_{i, t}
$$

\section{Firm value variable}

To investigate the effects of excess cash holdings on firm value, we use the regression equation presented by Fama and French[7]. Referring to study of Gu and Sun, we modify the equation appropriately[8]. In order to examine inverse Ushaped relationship between excess cash holdings level and firm value, we consider the two variables: excess cash holdings level and the square of it in equation. The final equation is as follow:

$$
\begin{aligned}
V_{i, t}= & \beta_{0}+\beta_{1} \text { SqExtracash }_{i, t}+\beta_{2} \text { Extracash }_{i, t}+\beta_{3} \frac{E_{i, t}}{N A_{i, t}}+\beta_{4} \frac{\Delta E_{i, t}}{N A_{i, t}} \\
& +\beta_{5} \frac{D_{i, t}}{N A_{i, t}}+\beta_{6} \frac{\Delta D_{i, t}}{N A_{i, t}}+\beta_{7} \frac{I_{i, t}}{N A_{i, t}}+\beta_{8} \frac{\Delta I_{i, t}}{N A_{i, t}}+\beta_{9} \frac{R \& D_{i, t}}{N A_{i, t}} \\
& +\beta_{10} \frac{\Delta R \& D_{i, t}}{N A_{i, t}}+\beta_{11} \frac{\Delta N A_{i, t}}{N A_{i, t}}+\beta_{12} \frac{\Delta M V_{i, t}}{N A_{i, t}}+\varepsilon_{i, t}
\end{aligned}
$$

Where $V$ denotes firm value, which is computed as the sum of the market value of equity and the book value of debt divided by NA; SqExtracash denotes the square of the excess cash holdings level; Extracash denotes the excess cash holdings level; $N A$ is net assets; $E$ is the total profits of a fiscal year; $D$ is common dividends paid; $I$ is interest expense; $R \& D$ is research and development expense; $M V$ is market value of a firm; $i$ and $t$ denotes the specific listed firms and the specific year respectively; $\Delta X$ denotes the change in variable $X$ from year $\mathrm{t}-1$ to year $\mathrm{t}$.

\section{The corporate life cycle variable}

The samples are listed firms which usually have gone through the start-up life cycle stage. Therefore we divide the samples into three corporate life cycles stages: growth, maturity and decline. Anthony and Ramesh choose the following four variables to describe the firm characteristic at different life cycle stages: sales growth, change in capital expenditure, annual dividend payout ratio and firm's age[9]. Since these four variables do not apply to classify Chinese firms into life cycle stages, we finally choose the following three variables to classify our samples into life cycle stages: sales revenue growth rate, capital expenditure rate and net profit growth rate[10].

We implement the following steps to divide our samples into three life cycle stages. First, we calculate the three variables for each sample. Sales revenue growth rate is defined as annual growth rate of sales revenue. Capital expenditure rate is defined as annual capital expenditure as a proportion of total assets. Net profit growth rate is defined as annual growth rate of net profit. Next, based on the value of each variable, we give the highest $1 / 3$ samples 3 points, the lowest $1 / 3$ samples 1 point, the middle $1 / 3$ samples 2 points and calculate the total score of all samples. The reason of using such rubrics is as follow. Owing to the rapid expansion of sales and investment, the capital expenditure rate, sales income growth rate and net profit growth rate are very high at growth life cycle stage. At the maturity life cycle stage, the sales income and net profit growth decline with the decreasing of growth opportunity. At decline life cycle stage, the capital expenditure rate, sales 
income growth rate and net profit growth rate continue to drop fast, since the firm growth decrease rapidly or even worse. Third, we classify the samples into eleven subsamples according to the industries that they belong to, since the differences in industries always exert some impacts on the sales income growth rate, capital expenditure rate and net profit growth rate of firms. Fourth, in every industry subsamples, we rank samples in an ascending order and then split the ranked samples into three equal parts. Finally, a sample in the highest part is classified as a growth life cycle stage sample; a sample in the middle part is classified as a maturity life cycle stage sample and a sample in the lowest part is classified as decline life cycle stage sample.

\section{Empirical results and discussions}

\section{A. Empirical results of effects of excess cash holdings on firm value}

Using the whole samples, we apply the regression model (4) to examine the impacts of excess cash holdings on firm value. The regression results are shown in the table I. As show in the table I, the coefficient of the SqExtracash is significantly negative, while that of Extracash is significantly positive. It means that the firm value increase at first then decrease with increasing in excess cash holdings. There is a significant inverse U-shaped relation exists between excess cash holdings level and firm value. According to the empirical results, the firm value reaches maximum when the value of excess cash holdings level is $83.94 \%$.

TABLE I Effects of Excess Cash Holdings on Firm Value

\begin{tabular}{|c|c|}
\hline variables & coefficient \\
\hline Constant & $2.7552(85.81)^{* * *}$ \\
\hline SqExtracash $_{i, t}$ & $-0.9615(-8.12)^{* * * *}$ \\
\hline Extracash $_{i, t}$ & $1.6142(10.73)^{* * *}$ \\
\hline$E_{i, t} / N A_{i, t}$ & $1.6851(7.17)^{* * *}$ \\
\hline$\Delta E_{i, t} / N A_{i, t}$ & $-0.8818(-4.83)^{* * *}$ \\
\hline$D_{i, t} / N A_{i, t}$ & $14.8131(13.20)^{* * *}$ \\
\hline$\Delta D_{i, t} / N A_{i, t}$ & $-6.7607(-5.95)^{* * *}$ \\
\hline$I_{i, t} / N A_{i, t}$ & $44.6375(0.68)$ \\
\hline$\Delta I_{i, t} / N A_{i, t}$ & $-2.82 \times 10-9(-1.44)$ \\
\hline$R \& D / N A_{i, t}$ & $32.6562(7.82)^{* * * *}$ \\
\hline$\Delta R \& D_{i, t} / N A_{i, t}$ & $-4.8310(-0.74)$ \\
\hline$\Delta N A_{i, t} / N A_{i, t}$ & $-1.6044(-17.03)^{* * *}$ \\
\hline$\Delta M V_{i, t} / N A_{i, t}$ & $0.3456(26.59)^{* * *}$ \\
\hline $\mathrm{N}$ & 8208 \\
\hline $\mathrm{F}$ & 134.02 \\
\hline $\mathrm{Adj} . \mathrm{R}^{2}$ & 0.1628 \\
\hline
\end{tabular}

Note: $* * *, * *$ and $*$ indicate significance at the $1 \%$ level, $5 \%$ level and $10 \%$ level respectively.

\section{B. Empirical results of effects of excess cash holdings on firm value at three life cycle stages}

We classify 8208 samples into 2668 growth life cycle stage samples, 2966 maturity life cycle stage samples and 2574 decline life cycle stage samples. We apply model (4) to examine the impacts of excess cash holdings on firm value at different life cycle stages. The regression results are shown in the table II. The regression results of three life cycle stage samples all show that the coefficient between SqExtracash and $V$ is negative and statistically significant. The coefficient between Extracash and $V$ is positive. The coefficients also indicate that the excess cash holdings have inverse U-shaped relationship with firm value. The firm value reaches maximum when the excess cash holdings level is $83.94 \%, 64.82 \%$ and $69.86 \%$ respectively at growth, maturity and decline life cycle stages. The optimal excess cash holdings level which makes the firm value reaches maximum of firms at growth life cycle stage is higher than that of firms at maturity and decline life cycle stages. And the optimal excess cash holdings level which makes the firm value reaches maximum of firms at decline life cycle stage is higher than that for firms at maturity life cycle stages. It means that the optimal excess cash holdings level is dropping first and then rising with the development of firm. The following two reasons could explain why that is so.

On the one hand, we can explain it from the perspective of severity of the financing constraints that the firm faced. Firms are always characterized by limited competition advantages and circumscribed outside financial resources at growth life cycle stage. It indicates that firms always faced serious financing constraints at growth life cycle stage. Therefore, obtaining enough external financing is hard for firms which are at growth life cycle stage. The investors always lose the faith in the firms which is at decline life cycle stage, because these firms always lose the advantages in marketing already and its profitability and growth are low. Thus, obtaining enough external financing is also hard for firms which are at decline life cycle stage. But firms always won the approval of the market and investors at the maturity life cycle stage, which means that the firms can obtain external financing easily. Thus, one of the reasons for that the optimal excess cash holdings level of firms at maturity life cycle stage is lower than that of firms at growth and maturity life cycle is that firms possess better financing conditions at maturity life cycle stage. Firms always own more investment opportunities at growth life cycle stage, which means that firms can use excess cash holdings more effectively at this stage. Thus the optimal excess cash holdings level of firms at growth life cycle stage is higher than that of firms at decline life cycle stage.

On the other hand, we can explain it from the perspective of severity of the agency conflicts that the firm faced. The agency problem of firms are not serious at growth life cycle stage, because the managers always served by founders. Generally speaking, firms always employ the professional managers to serve as the managers and apply procedural management at maturity life cycle stage. The agency conflicts become critical with the separation of ownership and control at 
maturity life cycle stage. Even though firms also face serious agency problems at decline life cycle stage, the managers may not exploiting excess cash to derive private benefits. The reason is that managers need to prevent firms from bankrupting or being acquired and then to keep their job. From the above analysis, we can conclude that facing more serious agency problem is also one of the reasons for that the optimal excess cash holdings level of firms at maturity life cycle stage is lower than that of firms at growth and maturity life cycle.

TABLE II Effects of Excess Cash Holdings on Firm Value at Three Life Cycle Stages

\begin{tabular}{|c|c|c|c|}
\hline variables & Growth & Maturity & Decline \\
\hline Constant & $\begin{array}{c}1.7071 \\
(30.06)^{* * * *}\end{array}$ & $\begin{array}{c}2.4470 \\
(40.71)^{* * *}\end{array}$ & $\begin{array}{c}2.9292 \\
(51.96)^{* * *}\end{array}$ \\
\hline$S_{\text {Extracash }}, t$ & $\begin{array}{c}-0.9374 \\
(-4.28)^{* * * *}\end{array}$ & $\begin{array}{l}-0.4924 \\
(-1.92)^{*}\end{array}$ & $\begin{array}{c}-0.6353 \\
(-4.44) * * *\end{array}$ \\
\hline Extracash $_{i, t}$ & $\begin{array}{c}1.6732 \\
(7.02)^{* * * *}\end{array}$ & $\begin{array}{c}0.6383 \\
(2.11)^{* *}\end{array}$ & $\begin{array}{c}0.8877 \\
(3.61)^{* * *}\end{array}$ \\
\hline$E_{i, t} / N A_{i, t}$ & $\begin{array}{c}11.1825 \\
(20.34)^{* * *}\end{array}$ & $\begin{array}{c}6.9694 \\
(14.83)^{* * *}\end{array}$ & $\begin{array}{c}-1.9397 \\
(-5.80) * * *\end{array}$ \\
\hline$\Delta E_{i, t} / N A_{i, t}$ & $\begin{array}{c}-3.5999 \\
(-6.87)^{* * *}\end{array}$ & $\begin{array}{c}-1.8499 \\
(-4.78)^{* * *}\end{array}$ & $\begin{array}{c}1.5866 \\
(6.17)^{* * *}\end{array}$ \\
\hline$D_{i, t} / N A_{i, t}$ & $\begin{array}{c}6.7793 \\
(4.73) * * *\end{array}$ & $\begin{array}{c}11.2646 \\
(5.32)^{* * *}\end{array}$ & $\begin{array}{c}16.7850 \\
(7.71)^{* * *}\end{array}$ \\
\hline$\Delta D_{i, t} / N A_{i, t}$ & $\begin{array}{l}1.9013 \\
(1.16)\end{array}$ & $\begin{array}{c}-0.0204 \\
(-0.01)\end{array}$ & $\begin{array}{c}-8.8704 \\
(-4.11) * * *\end{array}$ \\
\hline$I_{i, t} / N A_{i, t}$ & $\begin{array}{c}-189.0938 \\
(-0.97)\end{array}$ & $\begin{array}{c}71.2377 \\
(0.98)\end{array}$ & $\begin{array}{c}-400.5517 \\
(-0.86)\end{array}$ \\
\hline$\Delta I_{i, t} / N A_{i, t}$ & $\begin{array}{c}-4.44 \times 10^{-9} \\
(-0.60)\end{array}$ & $\begin{array}{c}-3.44 \times 10^{-9} \\
(1.14)\end{array}$ & $\begin{array}{c}4.30 \times 10^{-9} \\
(0.58)\end{array}$ \\
\hline$R \& D / N A_{i, t}$ & $\begin{array}{c}15.3298 \\
(3.06)^{* * *}\end{array}$ & $\begin{array}{c}50.3469 \\
(7.42)^{* * *}\end{array}$ & $\begin{array}{l}19.4018 \\
(2.07)^{* *}\end{array}$ \\
\hline$\Delta R \& D_{i, t} / N A_{i, t}$ & $\begin{array}{c}3.7370 \\
(0.48)\end{array}$ & $\begin{array}{c}-14.2866 \\
(-1.32)\end{array}$ & $\begin{array}{c}21.5163 \\
(1.50)\end{array}$ \\
\hline$\Delta N A_{i, t} / N A_{i, t}$ & $\begin{array}{c}-0.6257 \\
(-4.18)^{* * *}\end{array}$ & $\begin{array}{c}-1.5846 \\
(-9.11)^{* * *}\end{array}$ & $\begin{array}{c}-1.3265 \\
(-8.12)^{* * *}\end{array}$ \\
\hline$\Delta M V_{i, t} / N A_{i, t}$ & $\begin{array}{c}0.5244 \\
(29.80)^{* * * *}\end{array}$ & $\begin{array}{c}0.2980 \\
(13.50)^{* * * *}\end{array}$ & $\begin{array}{c}0.3147 \\
(12.60)^{* * *}\end{array}$ \\
\hline $\mathrm{N}$ & 2668 & 2966 & 2574 \\
\hline F & 190.71 & 64.71 & 32.88 \\
\hline Adj. $R^{2}$ & 0.4605 & 0.2050 & 0.1294 \\
\hline
\end{tabular}

Note: $* * *, * *$ and $*$ indicate significance at the $1 \%$ level, $5 \%$ level and $10 \%$ level respectively.

\section{Conclusions}

Based on the corporate life cycle theory, we demonstrate the effects of corporate excess cash holdings on firm value. We find that a significant inverse U-shaped relation exists between excess cash holdings level and firm value. It indicates that lots of companies face the problem of financing constraint. Holding some excess cash have positive influences on firm value. But the excess cash holdings exert negative influence on firm value when it exceeds a certain point. We also find that the optimal excess cash holdings which make the firm value reaches maximum are significantly different among firms at different life cycle stages.

Our work indicates that the managers should figure out which life cycle stage the corporate is at and make the cash holdings policy accordingly. In this way, the corporate cash holdings obviously become more reasonable.

\section{Acknowledgment}

The research is supported by the National Natural Science Foundation of China under Grant No.71340014, the Social Science Foundation of Hunan Province of China under Grant No.09YBA037, the Foundation for Innovative Research Groups of the Natural Science Foundation of Hunan Province of China under Grant No.09JJ7002, the Program for Chang Jiang Scholars and Innovative Research Team of Ministry of Education of China under Grant No.IRT0916.

\section{References}

[1] D. Cheng, S. Li, and C. Wang, "The quality of the government, the ultimate ownership and corporate cash holdings," Management World, no. 11, pp. 127-141, November 2011.

[2] S. Han, and J. Qiu, "Corporate precautionary cash holdings," Journal of Corporate Finance, vol. 13, no. 1, pp. 43- 57, January 2007.

[3] M. Belkhir, S. Boubaker, and I. Derouiche, "Control-ownership wedge, board of directors, and the value of excess cash," Economic Modelling, vol. 39, no. 4, pp. 110-122, April 2014.

[4] S. C. Myers, and N. S. Majluf, "Corporate financing and investment decisions when firms have information that investors do not have," Journal of Financial Economics, vol. 13, no. 2, pp. 187-221, February 1984.

[5] M. C. Jensen, "The agency costs of free cash flow: Corporate finance and takeovers," American Economic Review, vol. 76, no. 2, pp. 323329, February 1986.

[6] A. Dittmar, and J. Mahrt-Smith, "Corporate governance and the value of cash holdings," Journal of Financial Economics, vol. 83, no. 3, pp. 599-634, March 2007.

[7] E. F. Fama, and K. R. French, "Taxes, financing decisions and firm value," The Journal of Finance, vol. 53, no. 3, pp. 819-843, March 1998

[8] N. Gu and J. Sun, "The market value of cash: Evidence from Chinese listed firms," Management World, vol. 21, no. 4, pp. 96-104, April 2008.

[9] J. H. Anthony, and K. Ramesh, "Association between accounting performance measures and stock prices: A test of the life cycle hypothesis," Journal of Accounting and Economics, vol. 15, no. 2, pp. 203-227, February 1992.

[10] X. Wang, "Corporate life cycle and the creditor governance," Journal of Zhongnan University of Economics and Law, no. 1, pp. 129-136, January 2013. 